(C) Shut' S.V., Trybrat T.A., Ivanytska T.A., Goncharova O.O., Katrychenko L.O.

UDC 613.616 - 056.52- 02:616.1

DOI https://doi.org/10.31718/mep.2020.24.3-4.04

\title{
THE PUBLIC AWARENESS OF OVERWEIGHT AND OBESITY AS A RISK FACTOR FOR CARDIOVASCULAR DISEASES*
}

\author{
Shut' S.V., Trybrat T.A., Ivanytska T.A., Goncharova O.O., Katrychenko L.O.
}

Ukrainian Medical Stomatological Academy, Poltava, Ukraine

The present study is a part of the research work of the Department of Propaedeutics of Internal Medicine with Patients Care, General Practice (Family Medicine) of Ukrainian Medical Stomatological Academy «Features of the course of cardiovascular pathology in patients of different age categories, depending on the presence of components of metabolic syndrome and comorbid conditions, ways for correction of the revealed disorders and their prevention». State registration number 0119U102864.

В структурі нозологічних одиниць, асоційованих з наявністю надлишкової маси тіла (НМТ) і ожиріння (ОЖ), лідирує кардіоваскулярна патологія: з щорічних чотирьох мільйонів смертей у світі, пов'язаних з високим індексом маси тіла (IMT), понад дві третини $\epsilon$ випадками серцево-судинної смерті. Оцінювали обізнаність серед неорганізованого населення у віці від 20 до 82 років в кількості 280 чоловік щодо надмірної ваги та ожиріння. Встановлено, що досить поширені НMT та ОЖ як серед жінок $(20,71$ i 16,78\%, так і серед чоловіків (33,22\% i 11,79\% відповідно). Серед обстежених пацієнтів у 43,07\% чоловіків та у 53,31\% жінок спостерігався підвищений артеріальний тиск, а у 55,21\% чоловіків та у 60,70\% жінок виявлені різні зміни на електрокардіограмі, із них гіпертрофія лівого шлуночка спостерігалась в 57\%, яка є не лише компенсаторною реакцією, а одним із найбільш важливих незалежних факторів кардіоваскулярного ризику. Всім респондентам було запропоновано відвідуванні школи «Здоров'я»,де проводилась освітня програма з питань профілактики та корекції основних факторів ризику виникнення ожиріння та серцево-судинних захворювань,де основою була зміна способу життя, з акцентом, в першу чергу, для осіб з ССЗ, на збільшенні фізичної активності та зміні якісного складу раціону харчування ніж рестрикції його калорійності. Через 6 місяців проводилося повторне обстеження: із них нормалізували IMT: з НMT та ОЖ серед жінок (14,22 і 13,57\%,) так і серед чоловіків (23,21\% і 7,5\% відповідно), тим самим зменшився ризик серцево-судинних захворювань. Обізнаність населення щодо знань факторів ризику серцево-судинних захворювань знаходиться на низькому рівні. Дотримання здорового способу житт, раціональне харчування, проведення освітньої програми є частиною у веденні хворих з НМТ та ожирінням, що призводить до зниження ризику серцево-судинних захворювань.

Ключові слова: надмірна вага, ожиріння, фрактор ризику серцево-судинних захворювань, індекс маси тіла.

The cardiovascular pathology is a leading condition in the structure of clinical cases associated with overweight and obesity: more than two-thirds of cardiovascular mortality cases: annually, four million deaths worldwide are associated with a high body mass index (BMI). The awareness among the unorganized population aged from 20 to 82 years in the total number of 280 people was assessed. During the study it was found that overweight and obesity are quite common both among women (20.71 and $16.78 \%$ ) and men (33.22\% and $11.79 \%$, respectively). Among the examined patients, an elevated blood pressure and various changes of the electrocardiogram were detected, of which left ventricular hypertrophy was observed in 57\%, which is not only a compensatory reaction, but one of the most important independent factors for the cardiovascular risk. All respondents were offered to attend the Health Promotion School providing the educational program for prevention and correction of the main risk factors for obesity and heart diseases. The principle objective of this program was a change of lifestyle with a primary focus on patients with CVD, increased e physical activity and change of the quality of the diet rather than restricting its caloric value. The second survey was conducted in 6 months and the findings are as follows: BMI was corrected among overweight and obese female patients (14.22 and $13.57 \%)$, as well as among male patients (23.21\% and 7.5\%, respectively), thereby reducing the risk for cardiovascular diseases. The public awareness regarding the risk factors for cardiovascular diseases is considered to be low. Maintaining a healthy lifestyle, rational nutrition and educational program activities are the measures for management of overweight and obese patients resulting in reduction of the risk for cardiovascular diseases.

Key words: overweight, obesity, cardiovascular diseases risk factor, body mass index.

Optimisation of prevention remains one of the most pressing challenges for modern medicine regardless of the advances made in the prevention and treatment of cardiovascular diseases (CVD) during the last decades.

In most countries of the world, obesity is largely becoming one of the main risk factors for the development and progression of chronic non-communicable diseases [1], which is largely due to the ever-increasing rates of its prevalence [2]. At the same time, the cardiovascular pathology is a leading condition in the structure of clinical cases associated with overweight and obesity: annually, four million deaths worldwide are associated with a high body mass index (BMI), more than two-thirds are cardiovascular mortality cases [3].

Obesity is diagnosed in almost $30 \%$ of cases among the working-age population of Ukraine, whilst every fourth resident is overweight. Many countries of the world have a worrisome tendency towards the increase of the obesity incidence which on the average has doubled over the past 10 years. Estimations performed by the WHO experts revealed that the number of obese people worldwide will have reached 300 million persons by 2025 .

${ }^{*}$ To cite this English version: Shut' S.V., Trybrat T.A., Ivanytska T.A., Goncharova O.O., Katrychenko L.O. The public awareness of overweight and obesity as a risk factor for cardiovascular diseases // The Medical and ecological problems. - 2020. - Vol 24, № 3-4. - P. 15-18. 
The prevalence of obesity increases with age (up to the age of 64 years), it is more common among women, people with low levels of education and income, people engaged mainly in physical labor (Rennie K. L. et al., 2005). MS is diagnosed in $22-28 \%$ of cases among overweight people, whilst among patients with obesity - in $50-60 \%$.

A well-known prospective cohort Framingham Heart Study revealed that life expectancy of overweight 40 years-old nonsmokers is by 3.1 (for men) and by 3.3 (for women) years shorter; if obese, life expectancy is by 5.8 years shorter for men and by 7.1 years shorter for women. The life expectancy is as shorter as the greater is the severity of obesity and/or due to its development at a younger age.

Overweight and obesity (especially abdominal) increase the overall and cardiovascular morbidity and mortality being associated with almost predetermined development of hypertension, atherogenic dyslipidemia and diabetes mellitus among such patients precisely due to the development of insulin resistance and metabolic syndrome [4].

Obesity per se is recognized as a proinflammatory and procoagulant condition since the macrophages of the bone marrow origin, contributing to the production of the tumor necrosis factor $\alpha$ (TNF- $\alpha$ ), IL-6 and IL-1, are accumulated in the adipose tissue by means of excessive synthesis of chemoattractant MSR-1 by adipocytes.

The content of insulin resistance inducers (TNF- $\alpha$, IL6 , leptin, resistin) increases, the synthesis of adiponectin as the insulin sensitizer is inhibited among obese patients. In addition, excessive synthesis of angiotensinogen, plasminogen activator inhibitor, metalloprotease and adhesion molecules are activated by adipocytes.

Abdominal obesity is usually associated with atherogenic dyslipidemia (decreased levels of the HDL cholesterol and hypertriglyceridemia) being the cause for the accelerated atherogenesis [5].

The contribution of high BMI values as a factor for CVD [6] is determined by the results of meta-analyses of numerous prospective studies demonstrating the presence of a J-shaped association of this indicator with the overall and cardiovascular mortality with a minimum level of the latter in the range from $20.0(22.5) \mathrm{kg} / \mathrm{m} 2$ to $25 \mathrm{~kg} /$ $\mathrm{m} 2[7,8]$.

The aim of the research was to assess the level of public awareness regarding overweight and obesity.

\section{Material and methods}

The public awareness regarding overweight and obesity as a risk factor for cardiovascular diseases was studied and assessed among the unorganized population aged from 20 to 82 years old in the total of 280 people.

The following formula was applied: Body mass index $(\mathrm{BMI})=$ body weight $(\mathrm{kg}) /$ height $\left(\mathrm{m}^{2}\right)$ was used for quantitative assessment of the body weight and the severity of obesity. BMI is a simple and fairly informative indicator, the value of which is directly related to the risk of morbidity and mortality. Body weight was estimated as normal with a BMI below $25 \mathrm{~kg} / \mathrm{m}^{2}$ in $49(17.5 \%)$ patients, as an excess with a BMI of $25.0-29.9 \mathrm{~kg} / \mathrm{m}^{2}$ - among 93 male patients $(33.22 \%)$, among 58 female patients $(20.71 \%$,); obesity with BMI above $30 \mathrm{~kg} / \mathrm{m}^{2}$, among 33 men (11.79\%), 47 women $(16.78 \%$,).

The survey of the population using a questionnaire was conducted to identify their awareness regarding overweight, obesity and its complications.

Blood pressure (BP) measurements were performed twice on both hands with an interval of at least 5 minutes. The resting ECG was taken on a Yukard-100 electrocardiograph in 12 conventional leads. The statistical processing of the obtained data was conducted by the method of variation statistics using the Microsoft Excel.

\section{Results and discussion}

During the study, it was found that overweight and obesity are quite common both among women (20.71 and $16.78 \%)$ and men $(33.22 \%$ and $11.79 \%$, respectively) (Fig. 1).

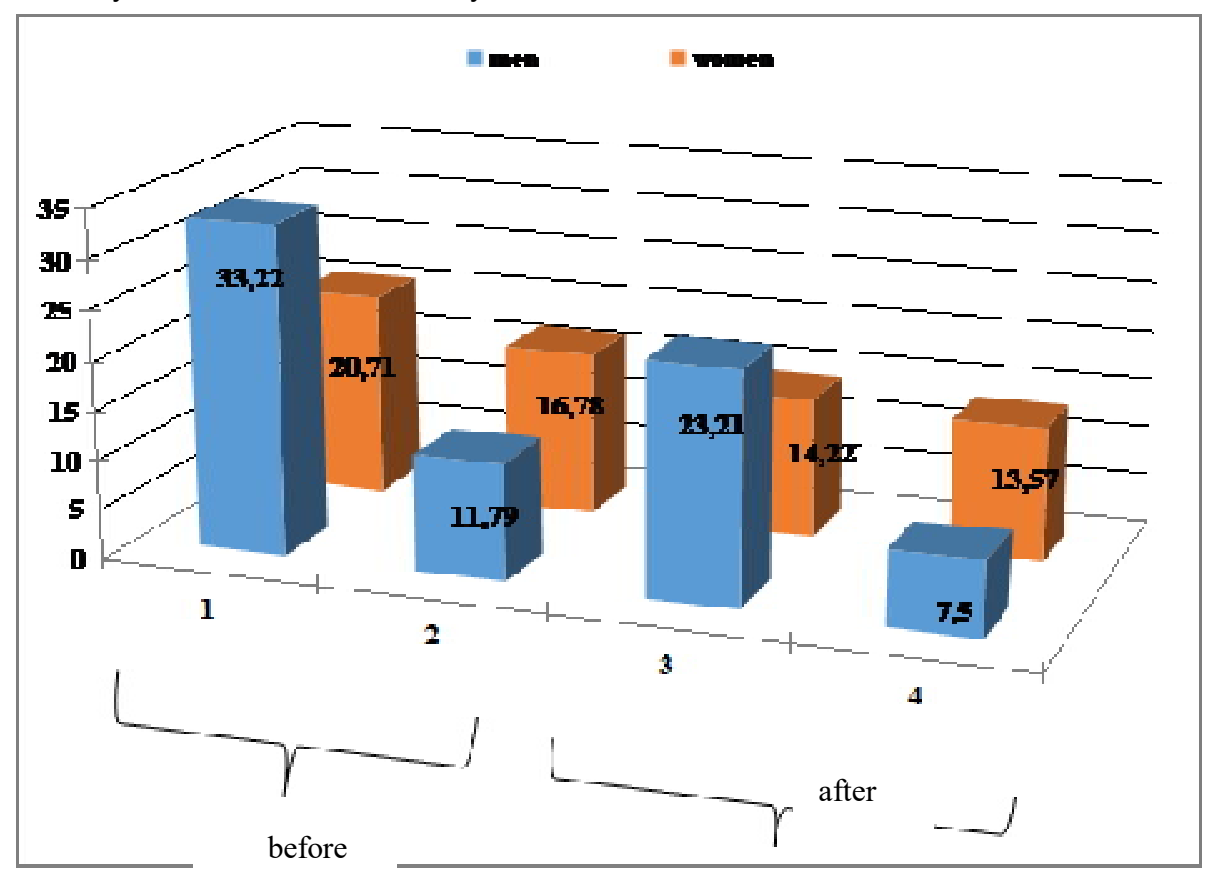

Fig. 1. The level of overweight and obesity among the study subjects before and after attending the Health Promotion School 
Overweight is more prevalent among men in Ukraine and Europe, whereas obesity is common among female patients.

Among the assessed patients, $43.07 \%$ of men and $53.31 \%$ of women had high blood pressure, whilst various changes on ECG were detected among $55.21 \%$ of men and $60.70 \%$ of women (Fig. 2.)

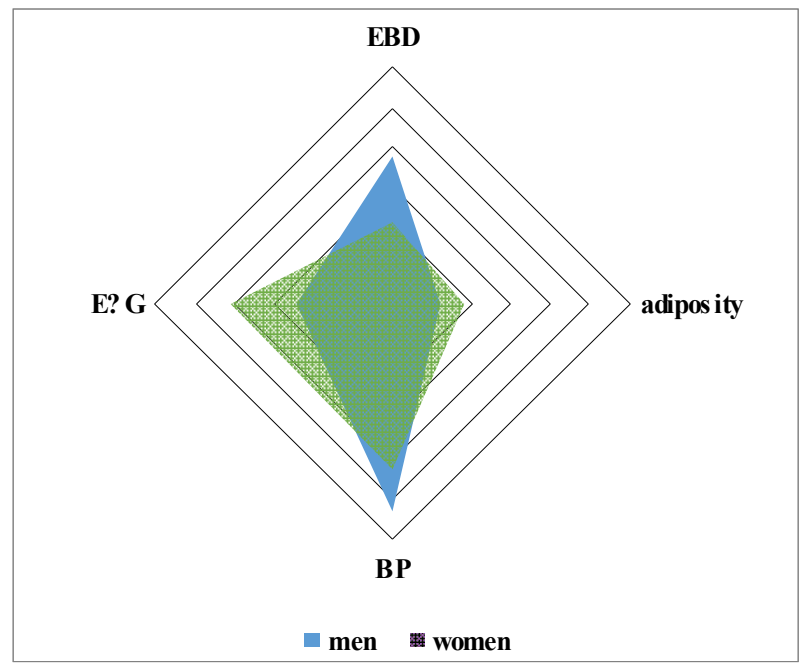

Fig. 2. The blood pressure and ECG findings among the study subjects

As of today, LVH is considered not only a compensatory reaction aimed at reducing the load per unit mass of the myocardium in hypertension, but also as one of the most important independent factors of cardiovascular risk. Its negative effect on survival is associated with a decrease of the coronary reserve, failed endothelial and diastolic LV function, the development of ventricular arrhythmias and thromboembolic complications of atrial fibrillation.

Pathogenetically, LVH is associated with other risk factors - hemodynamic (the degree of BP - pressure and volume overload; high pulse BP - via increased arterial stiffness; the effect of morning surge in BP), demographic (age, male gender, race) and lifestyle (physical activity, salt sensitivity, obesity, insulin resistance/hyperinsulinemia, hyperactivation of the sympathoadrenal and renin-angiotensin-aldosterone systems, endothelial dysfunction and inflammation). For patients having $\mathrm{LVH}$ along with hypertension or with high normal BP, the cardiovascular risk is assessed as high, thus requiring early medicinal treatment, lower target BP values and strict control of the other risk factors. It is assumed that the RAAS tissue is "responsible" for the development of inflammation, fibrosis, hypertrophy and atherosclerosis. It is also known that the activity of RAAS is largely genetically determined. Hyperinsulinemia also increases the content of angiotensin II and the density of type 1 receptors to it in the ventricular myocardium. Angiotensin II as an activator of nuclear transcription factor NF-kB is an inflammatory factor and a stimulant of interstitial myocardial fibrosis and vasoconstriction, and the content of angiotensin II correlates with the LV myocardial mass. Hyperaldosteronism contributes to sodium and fluid retention and heart fibrosis.

The survey was conducted among all patients to identify their awareness regarding the overweight and its complications. Almost every third overweight (37.11\%) and obese $(31.98 \%)$ women do not believe that the excess body weight increases the cardiovascular risk.
$18.87 \%$ of overweight women and $16.23 \%$ of obese women do not consider their existing overweight as a risk factor for CVD at all. Overweight (31\%) and obese $(37.80 \%)$ men do not consider overweight as an important risk factor.

It has been proven that weight loss by $10 \mathrm{~kg}$ in obese patients leads to a $20 \%$ reduction in overall mortality and a $30 \%$ reduction in diabetes-associated morbidity (which are usually caused by cardiovascular complications).

Maintaining a healthy lifestyle and its modification in the presence of cardiovascular risk factors are the basis of up-to-date recommendations. Therefore, all respondents were offered to attend the Health Promotion School providing the educational program for prevention and correction of the main risk factors for obesity and heart diseases. The principle objective of this program was a change of lifestyle with a primary focus on patients with $C V D$, increased physical activity and change of the quality of the diet rather than restricting its caloric value. [9].

Measures to correct the caloric values (limit by 500 600 kilocalories on average) and qualitative composition (reduction of saturated fats and fast-digested carbohydrates) of the daily diet, as well as dietary pattern in most expert documents are the basis for all treatment and prevention interventions in overweight and obese patients [10], given the compliance, accompanied by a decrease of BMI, percentage of adipose tissue, reduction of visceral obesity $[11,12]$. At the same time, recommendations concerning the reduction of the daily caloric intake should be preceded by assessing the output parameters of the diet in relation to the patient's energy demands, in order to avoid in particular cases, the greater reduction in the rate of basic metabolism.

The second check-up was conducted in 6 months and the findings are as follows: BMI was corrected among overweight and obese female patients (14.22 and $13.57 \%)$, as well as among male patients $(23.21 \%$ and $7.5 \%$, respectively), thereby reducing the risk for cardiovascular diseases.

Conclusions: The public awareness regarding the risk factors for cardiovascular diseases is considered to be low. Maintaining a healthy lifestyle, rational nutrition and educational program activities are the measures for management of overweight and obese patients resulting in reduction of the risk for cardiovascular diseases.

\section{References}

1. Lim S, Vos T, Flaxman A, et al. A comparative risk assessment of burden of disease and injury attributable to 67 risk factors and risk factor clusters in 21 regions, 19902010: a systematic analysis for the Global Burden of Disease Study 2010. Lancet 2012; 380 (9859): 2224-60.

2. Marie N, Fleming $T$, Robinson $M$, et al. Global, regional, and national prevalence of overweight and obesity in children and adults during 1980-2013: a systematic analysis for the Global Burden of Disease Study 2013. Lancet 2014; 384: 766-81.

3. The GBD 2015 Obesity Collaborators. Health Effects of Overweight and Obesity in 195 Countries over 25 Years. N Engl J Med 2017; 377: 13-27.

4. Ivanytska TA, KazakovYuM, Guminsky Jul. The role of insulin resistance in the development of endothelial dysfunction in essential hypertension in young patients.Bulletin of problems biology and medicine. 2019; 2, 2 (151): 44-48

5. http://www.mif-ua.com/archive/article/6915

6. Piepoli M, Hoes A, Agewall S, et al. European Guidelines on cardiovascular disease prevention in clinical practice (version 2016). European Heart Journal 2016; 37 (29): 2315- 81 . 
ToM 24, N 3-4 2020 p.

7. The Global BMI Mortality Collaboration. Body-mass index and all-cause mortality: individual participant-data metaanalysis of 239 prospective studies in four continents. Lancet 2016; 388: 776-86.

8. Aune D, Sen A, Prasad M, et al. BMI and all-cause mortality: systematic review and nonlinear dose-response metaanalysis of 230 cohort studies with 3.74 million deaths among 30.3 million participants. BMJ 2016; 353: i2156.

9. Neeland I, Poirier P, Després J. Cardiovascular and Metabolic Heterogeneity of Obesity Clinical Challenges and Implications for Management. Circulation.2018;137:1391406.

10. Piepoli M, Hoes A, Agewall S, et al. European Guidelines on cardiovascular disease prevention in clinical practice (version 2016). European Heart Journal. 2016;37(29):2315- 81.

11. Trybrat TA, Shut SV, Sakevich VD, Goncharova OO. Commitment to treatment of patients with ischemic heart disease as an effective factor of prevention. Bulletin of problems of biology and medicine .2019; 1,1 (148): 185188

12. Trybrat TA, Shut SV, Shepitko VV. Relationship of compliance with individual characteristics of patients. Bulletin of problems of biology and medicine.2017;4,1 (139): 275-277

Матеріал надійшов до редакції 03.06.2020. 